\title{
The Effect Of Passive Range Of Motion (ROM) on Increasing Elbow Joint Angles of Stroke Patients
}

\author{
Yurida Olviani ${ }^{1}$, Irfan Maulana ${ }^{2}$, Syarifah Salmah $^{3}$ \\ \{yurida.aurora@gmail.com ${ }^{1 *}, \underline{\text { irfanmaulana18@gmail.com }}{ }^{2}, \underline{\text { syarifahsalma373@gmail.com }}^{3}$ \} \\ ${ }^{13}$ Faculty of Nursing \& Health Sciences, University of Muhammadiyah Banjarmasin, Indonesia \\ ${ }^{2}$ Ratu Zalecha General Hospital Martapura South Kalimantan, Indonesia \\ *yurida.aurora@gmail.com
}

\begin{abstract}
Physical exercise that can be done in stroke patients is passive Range of Motion exercises that function to increase joint mobilization. This study aimed to determine the effect of passive Range of Motion on increasing angular joint angles of stroke patients. The research used quasi experiment with a pre-post design in one group, the number of samples was 30 respondents with consecutive sampling technique. The measuring instrument used was goniometer and observation sheet. The subjects in this study were stroke patients. Based on the results of the study the difference in angle of flexion elbow joint is $6.7^{\circ}$ and the difference in angle of extension of the elbow joint is $8.3^{\circ}$. Paired T-Test statistical results obtained value of $\rho$ value $0,000 \leq 0,05$, which shows there is an effect of passive Range of Motion influence on increasing the angle of the elbow joint of stroke patients.
\end{abstract}

Keywords: Passive Range of Motion, Increasing Elbow Joint Angle, Stroke

\section{Introduction}

Stroke is one of the dangerous diseases. It injures the brain [1] because of a clot blocking an artery or a burst artery [2]. Therefore, stroke as a neurological disease can lead to serious health problems. It also can lead to disability and death. Stroke and Ischaemic heart disease are the world's biggest killers with 15.2 million deaths in 2016 [3]. For the last 15 years, these diseases have remained the leading causes of death in the world wide. Based on data from the World Health Organization (2016) that stroke is the second most common cause of death and the sixth most common cause of disability. In ASEAN, stroke is the fourth cause of death and Indonesia is number one [4]. While in South Kalimantan, stroke is the top four for high prevalence in Indonesia.

The biggest impact on stroke patients are the weaknesses of muscle, therefore they have to practice Range of Motion (ROM) to maintain mobility joints, to simulate circulation and to preserve muscle strength [2]. Range of Motion (ROM) is joint movements that allow for contraction and muscle movement both passively and actively [5]. Passive ROM excercises are routine nursing procedures appropriate for stroke patients [6]. This study is to determine the effect of passive Range of Motion on increasing angular joint angles of stroke patients in Seruni Ward of Banjarmasin Ulin General Hospital.

\section{Research methods}

This study used a pre-experimental design method with pre-test and post-test (one group pre-post test design). The population in this study was the patient's stroke suffered upper extremity hemiparesis on male or female. The sampling technique in this research was by using consecutive sampling. This research was conducted in the Seruni Ward of 
Banjarmasin Ulin General Hospital from 29 October to 27 November 2018 and got 30 respondents. The research instruments were used is a goniometer, observation sheet, and passive Range of Motion (ROM) Standard Operational Procedure (SOP).

\section{Results and Discussion}

Table 1. Distribution of influence Passive Range of Motion (ROM) to an increase in the angle joints elbow patients with stroke.

\begin{tabular}{lcc}
\hline \multicolumn{2}{c}{ Passive Range of Motion (ROM) } & \multicolumn{2}{c}{ Pre-Test Average } \\
\hline Flexion & $66.3^{\circ}$ & \\
Extension & $144.3^{\circ}$ & $152.6^{\circ}$ \\
\hline
\end{tabular}

Table 1 shows that the angle of flexion of the elbow joint respondent before being given a passive Range Of Motion (ROM) in pretest average of $66.3^{\circ}(21)$ and the angle of the elbow joint flexion after giving respondents passive Range Of Motion (ROM) in posttest an average of $59.67^{\circ}(20.5)$, while the angle of the elbow joint respondents extension before being given a passive range of motion (ROM) passive in pretest averaged $144.3^{\circ}(21.9)$ and the angle of the elbow joint respondent extension after administration of Passive Range of Motion (ROM) in posttest averages $152.6^{\circ}$ (21.6). As for the changes in elbow joint flexion after a passive Range of Motion (ROM) is average $6.67^{\circ}(7.9)$ and changes in the angle of the elbow joint extension after a passive Range of Motion (ROM) is average of -8.3 (10.7).

The results of the study showed that the majority of respondents' length of stay in this study was 1-5 days, as many as 19 people (63.3\%). The results of this study are in line with the results of research conducted by [7] which states that the length of stroke patient care is in a total of days. Respondents who had a stroke were treated for at least 4 days and the longest being treated at 15 days. It is also in accordance with the theory of [8] that in general, a person with stroke will be treated for at least 4 days. Other theories that support is according to [9] that factors which influence the length of stay of patients in hospitals include: treatment procedures, history of previous illnesses, as well as the severity of the disease. In addition, the length of stay is also influenced by decreased endurance, resulting in a longer recovery period, an extended stay and can generally increase the patient's morbidity and mortality.

Respondents who entered the inclusion criteria were male and female patients, early adulthood to elderly ( $26->65$ years). The results showed that the majority of respondents were aged 52-61 years as many as 9 people (30\%) which is the age of the late elderly. This is consistent with the theory based on the results of [4] showing an increasing trend in cases of stroke both in terms of death, incidence and disability, the death rate based on age is $15.9 \%$ (aged 45-55 years), 26, 8\% (age 55-64 years) and 23.5\% (age> 65 years). The results of this study are in line with the theory of [10] Age and gender are two of the stroke risks factors that cannot be modified. Stroke can affect all ages, but more often found in the elderly population. After 50 years of age, the risk multiplies every ten years.

The results of the study showed that the majority of respondents in this study were 18 male people $(60 \%)$. American Heart Association revealed that more frequent strokes occur in males than females as evidenced by research results showing that the prevalence of stroke more in men [11]. Some specific stroke risk factors are known to affect each gender. This related to the results of research in Nigeria entitled Gender Variation Risk Factors and Clinical Presentation of Acute Stroke, which found that risk factors for smoking habits and history of alcohol consumption were found to be more dominant in male respondents and significantly different from female respondents [12]. 
The majority of respondents in this study had a history of stroke of 17 people (56.7\%). The Stroke Association in UK also showed that the possibility of recurrent strokes is within one month, one year, five years and ten years [12]. The results of The Minnesota Stroke Survey which states that the incidence of stroke will recur within a span of ten years [13].

The majority of respondents in this study had a history of other diseases, namely hypertension of 8 people (26.7\%). Based on [14] which states that blood pressure above 140 $\mathrm{mmHg}$ is included as a variable that is proven to have a relationship with the incidence of stroke. This is also consistent with the stroke compendium which stated that hypertension was the highest risk factor in the incidence of stroke. The higher the patient's blood pressure the greater the possibility of a stroke, due to damage to the walls of blood vessels making it easier for blockages and even rupture of blood vessels in the brain [15].

\subsection{Bivariate Analysis}

Table 2. Difference angle joints elbow flexion and extension before and after giving passive Range Of Motion (ROM) against increasing angle joints elbow on stroke patient

\begin{tabular}{ccccc}
\hline $\begin{array}{c}\text { Passive Range of Motion (ROM) } \\
\mathrm{n}=30\end{array}$ & The Mean $\left({ }^{\circ}\right)$ & Elementary School & T & p value \\
\hline Flexion Pre-Test Post-Test & 66.3 & 21 & \multirow{2}{*}{4,614} & \\
& 59.67 & 20.5 & & 0,000 \\
Extension Pre-Test Post-Test & 144.3 & 21.9 & 4,236 & \\
& 152.6 & 21.6 & & \\
\hline
\end{tabular}

According to the table 2 from the Paired T-Test statistical test, earned an average (mean) that angle joints elbow flexion before given treatment was $66.3^{\circ}(\mathrm{SD}=21)$ and after a given treatment gained $59.6^{\circ}(\mathrm{SD}=20,5)$. A decrease in mean angle of the elbow joint flexed before and after treatment was $6.7^{\circ}$. Value $t$ count $=4.614$ value $t$ table $=2.045$. Because the value of $\mathrm{t}$ arithmetic $>\mathrm{t}$ table, so Ho is rejected and Ha is accepted. It means that there is an effect of Range of Motion (ROM) on the increase in angular joints of stroke elbow patients. In addition it also obtained the value of $\rho$ value $=0,000$ with level of significant of $\rho$ is $\rho \leq 0,05$, so the value of $\rho$ value that is smaller than the value of the level of significant $(0,000 \leq 0.05)$, therefore Ho rejected and $\mathrm{Ha}$ accepted, is meaning their differences in the average (mean) angle joints elbow flexion before and after given treatment to increase the angle joints elbow patients with stroke.

Paired T-Test statistical test results have obtained an average (mean) angle of the elbow joint extension before being treated was $144.3^{\circ}(\mathrm{SD}=21.9)$, after being given treatment obtained $152.6^{\circ}(\mathrm{SD}=21.6)$. An increase in the mean angle of the elbow joint extension before and after treatment was $8.3^{\circ}$. Value $t$ count $=4.236$ value $t$ table $=2.045$. Because the value of $\mathrm{t}$ arithmetic $>\mathrm{t}$ table then Ho is rejected and $\mathrm{Ha}$ is accepted, it means that there is an effect of Range of Motion (ROM) on the increase in angular joints of stroke elbow patients. In addition it also obtained the value of $\rho$ value $=0,000$ with level of significant of $\rho$ is $\rho \leq 0,05$, so the value of $\rho$ value that is smaller than the value of the level of significant $(0,000 \leq 0.05)$, therefore Ho rejected and Ha accepted, are meaning there differences in the average (mean) angle joints elbow flexion before and after given treatment to increase the angle joints elbow patients with stroke in Seruni Ward of Banjarmasin Ulin General Hospital in 2018.

The results of this study indicate that there is an effect of Passive Range of Motion $(\mathrm{ROM})$ on the increase in angle of the elbow joint before and after treatment for stroke 
patients in the Seruni Ward of Banjarmasin Ulin General Hospital with a p value of 0,000 . In accordance with the theory of passive Range of Motion (ROM) can increase the range of flexion and extension joints [15].

Passive Range of Motion (ROM) is a Range of Motion (ROM) exercise that is done by the patient with the help of nurses every movement. ROM exercise can cause stimulation so that it can activate neuromuscular and muscular chemical processes [16]. Stimulation through neuromuscular will increase stimulation in limb muscle fibers especially parasympathetic nerves which stimulate the production of acetylcholine, thus resulting in contractions. Contractions and relaxation during passive ROM motion performed in stroke patients occur with stretching of muscle fibers and an increase in blood flow in the elbow joint area resulting in an increase in the range of flexion-extension joints in the elbow joint [15].

The results of this study are in accordance with [17] which stated Range of Motion exercises were conducted to normalize the range of joint motion. Range of Motion exercises will cause the surface of the cartilage between the two bones to rub against one another. Cartilage contains a lot of protein glycemic which attach to hyaluronic acid and is hydrophilic. Emphasis on cartilage due to movement will force water out of the cartilage matrix into the synovial fluid, the activity in the joints will maintain synovial fluid which is a lubricant for the joints so that the joints can move optimally. The shortened muscle tissue will extend slowly when practiced by Range of Motion and the muscle tissue will begin to adapt to restore muscle length to normal.

\section{Conclusion}

Based on the analysis of researchers reinforced by supporting research related journals, it can be concluded that this action is beneficial to increase joint mobilization so that the activity in the joints will stimulate the release of synovial fluid which becomes a lubricant so that the joints can move optimally. In addition, it can prove and support that nonpharmacological measures namely Passive Range of Motion (ROM) can increase angle the elbow joints especially stroke patients.

\section{References}

[1.] Rogers JM, Duckworth J, Middleton S, Steenbergen B, Wilson PH. Elements virtual rehabilitation improves motor, cognitive, and functional outcomes in adult stroke: Evidence from a randomized controlled pilot study. J Neuroeng Rehabil. (2019).

[2.] Susanti S, Susanti S, BIstara DN. Pengaruh Range of Motion (ROM) terhadap kekuatan otot pada pasien stroke. J Kesehat Vokasional. (2019).

[3.] World Health Organization. The top 10 causes of death [Internet]. World Health Organization. (2018). [cited 2019 Dec 7]. Available from: https://www.who.int/newsroom/fact-sheets/detail/the-top-10-causes-of-death

[4.] Agianto A, Setiawan H. Supportive care needs pada keluarga pasien stroke di klinik syaraf Banjarmasin, Indonesia. Dunia Keperawatan. (2017).

[5.] Winstein CJ, Stein J, Arena R, Bates B, Cherney LR, Cramer SC, et al. Guidelines for adult stroke rehabilitation and recovery: A guideline for healthcare professionals from the American Heart Association/American Stroke Association. (2016).

[6.] Griffiths R, Hall J. Intensive care unit-acquired weakness. Crit Care Med. (2010)

[7.] Herminawati L, July J. Il-4: Prediktor Anti Inflamasi Pada Stroke Iskemik? Medicinus. (2018)

[8.] Rahayu S, Utomo W, Utami S. Hubungan frekuensi stroke dengan fungsi kognitif di 
RSUD Arifin Achmad. J Med PSIK. (2014).

[9.] Nursalam. Metodologi penelitian ilmu keperawatan pendekatan praktis. (2015)

[10.] Appelros P, Stegmayr B, Terent A. Sex differences in stroke epidemiology: A systematic review. Stroke. (2009).

[11.] American Heart Association. Heart disease and stroke statistics 2018 at a glance. American Stroke Association. (2018).

[12.] Watila MM, Nyandaiti YW, Bwala SA, Ibrahim A. Gender variation in risk factors and clinical presentation of acute stroke, Northeastern Nigeria. J Neurosci Behav Heal. (2011).

[13.] Lakshminarayan, Kamakshi Berger K. A, Fuller CC, Jacobs DR, Anderson DC, Steffen LM, Sillah A, et al. Trends in ten-year survival of stroke patients hospitalized between 1980 and 2000: The Minnesota Stroke Survey. Stroke. (2014).

[14.] Li C, Engstrom G, Hedblad B, Berglund G, Janzon L. Blood pressure control and risk of stroke: A population-based prospective cohort study. Stroke. (2005).

[15.] Boehme AK, Esenwa C, Elkind MSV. Stroke risk factors, genetics, and prevention. Circ Res. (2017)

[16.] Slater CR. The structure of human neuromuscular junctions: Some unanswered molecular questions. Int J Mol Sci. (2017).

[17.] Kim SH, Kwon OY, Park KN, Jeon IC, Weon JH. Lower extremity strength and the range of motion in relation to squat depth. J Hum Kinet. (2015). 